\title{
Length-weight relationship and condition factor of three endemic fish species, Ponticola bathybius, Neogobius caspius and Neogobius pallasi (Perciformes: Gobiidae) from the Southern Caspian Sea basin, Iran
}

\author{
Nasrin Nikmehr ${ }^{1}$ • Soheil Eagderi2* $\bullet$ Hadi Poorbagher ${ }^{3} \bullet$ Keyvan Abbasi $^{4}$ \\ ${ }^{1}$ Department of Fisheries, Faculty of Natural Resources, University of Tehran, Karaj, Iran \\ 2 Department of Fisheries, Faculty of Natural Resources, University of Tehran, Karaj, Iran \\ ${ }^{3}$ Department of Fisheries, Faculty of Natural Resources, University of Tehran, Karaj, Iran \\ ${ }^{4}$ Research Institute, Agricultural Research, Education and Extension Organization, Bandar Anzali, Iran

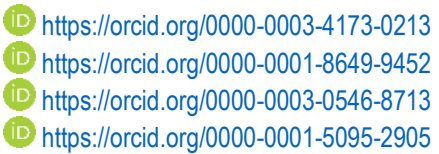

Nikmehr, N., Eagderi, S., Poorbagher, H. \& Abbasi, K. (2021). Length-weight relationship and condition factor of three endemic fish species, Ponticola bathybius, Neogobius caspius and N. pallasi (Perciformes: Gobiidae) from the Southern Caspian Sea basin, Iran. Ege Journal of Fisheries and Aquatic Sciences, 38(4), 523-525. DOI: 10.12714/egejfas.38.4.14

Abstract: In this study, the length-weight relationships (LWRs) and condition factors were estimated for 445 specimens belonging to three gobiid species viz. Ponticola bathybius (Kessler, 1877), Neogobius caspius (Eichwald, 1831) and Neogobius pallasi (Berg, 1916) from the Southern Caspian Sea basin. Total length and total weight of the examined specimens ranged $4.9-28.3 \mathrm{~cm}$ and $0.64-263.4 \mathrm{~g}$, respectively. The length-weight parameter $b$ of the studied species found between 2.47 ( $N$. caspius) and 3.45 (N. pallasi) with $r^{2}$ ranging 0.831 to 0.988 . LWR and K parameters are reported first time for $N$. pallasi from the Caspian Sea basin. The condition factor estimated was calculated from 0.94 (N. pallasi) to 0.98 (N. caspius) and 1.00 (P. bathybius). The basic biological information on the LWRs of these three gobies will be useful as baseline information for further biological research in the region.

Keywords: Gobiidae, goby, condition factor, Southern Caspian Sea basin

\section{INTRODUCTION}

Study of the length-weight relationship (LWR) is important in fisheries science as it provides valuable information on fish condition (Bagenal, 1978). It is applied to compare the interregional morphological variation of a single species' populations (Froese, 2006; Ali et al., 2013), to estimate the weight of a specimen from its length and vice versa, to estimate the biomass, understanding the life cycle, evaluation of the fish stocks, ontogenetic changes and growth studies (Froese, 2006; Cherif et al., 2008; Mouludi-Saleh and Eagderi, 2019; Eagderi et al., 2020a; Eagderi et al., 2020b; Mouludi-Saleh et al., 2021).

Condition factor $(K)$ states condition of fish species viz. well-being of a certain species and its degree of fatness, the state of sexual maturity, the degree of food sources availability, and age and sex of some species and is significance for management and conservation of natural populations (Bagenal, 1978; Sarkar et al., 2009; Muchlisin et al., 2010).

In the Iranian coast of the Caspian Sea, 43 species of the family Gobiidae in 15 genera have been reported (Esmaeili et al., 2018; Eagderi et al., 2020c). The species members of the genus Neogobius is three (Froese and Pauly, 2008; Esmaeili et al., 2018; Eagderi et al., 2020c) and those of the genus Ponticola is six in the southern Caspian Sea (Eagderi et al., 2020c). These genera are great importance due to their relatively large size (10 to $35 \mathrm{~cm}$ ) (Berg, 1949; Rahimov, 1991). Therefore, in this study, LWRs and K are provided for Ponticola bathybius, Neogobius caspius and N. pallasi from the Southern Caspian Sea basin.

\section{MATERIAL AND METHODS}

A total of 165 specimens of $P$. bathybius, $102 \mathrm{~N}$. caspius and 178 N. pallasi were collected between September 2012 and April 2019 using seine nets (mesh size: 4, 6 and $8 \mathrm{~mm}$ ) from The Anzali Wetland, Turkman, Langrud, Chaboksar, Sefidroud and Lisar shores of the Southern Caspian Sea. All sampled fishes were anesthetized with a $1 \%$ clove oil solution and fixed with $10 \%$ buffered formalin then transferred to the laboratory for further studies. For each specimen, total length $(T L)$ was measured with a digital caliper to the nearest 0.01 $\mathrm{mm}$ and body weight $(B W$ was recorded using a digital scale to the nearest $0.1 \mathrm{~g}$.

The length-weight relationship was determined by the method of least squares using the equation of $W=a L^{b}$ and logarithmically transformed into $\log (W)=\log (a)+b \log (L)$ (Froese, 2006), where $W$ is the total body weight $(\mathrm{g}), L$ is the total length $(\mathrm{cm})$ and " $a$ " is the intercept and " $b$ " is the slope. Prior to regression analyses, log-log plots of the lengthweight pairs were performed to identify outliers (Froese et al., 2011). Outliers perceive in the log-log plots of all species were removed from the regression. The student's t-test (ts) 
was used to determine whether the parameter $b$ is significantly different from the expected or theoretical value of 3. Fulton's condition factor $(K)$ was estimated by the equation: $K=100 \times\left(W / T L^{3}\right)$ (Fulton, 1904), where $W$ is the total body weight $(\mathrm{g}), \mathrm{L}$ is the total length $(\mathrm{cm})$ and scaling factor of 100 was used to fetch the $\mathrm{K}$ close to the unit factor. All statistical analyses were performed in Excel 2016 and PAST v 2.17b (Hammer et al., 2001) software.

\section{RESULTS AND DISCUSSION}

The length-weight relationship (LWR) data of fish species is an important parameter in their dynamic population studies, playing a key role in fisheries assessments. In the current study, LWR parameters of 445 gobiid fishes belonging to three species were estimated. Total lengths and weight of
$P$. bathybius, $N$. caspius and $N$. pallasi ranged $6.95-28.36 \mathrm{~cm}$, 2.3-263.4 g and $8.20-13.20 \mathrm{~cm}, 7.0-21.6 \mathrm{~g}, 4.92-12.55 \mathrm{~cm}$ and $0.6-24.6 \mathrm{~g}$, respectively. The results of LWR data of the three studied species, including values of the slope parameter (b), intercept (a), coefficient of determination $\left(r^{2}\right)$ and $95 \% \mathrm{CL}$ of $b, a$ and condition factor $(K)$ of the studied species are presented in Table 1.

The results showed $b$-values of the studied species ranging 2.47 ( $N$. caspius) to 3.45 (N. pallasi) and coefficient of determination $\left(r^{2}\right) 0.83$ to 0.98 , indicating the length increased with increasing weight of the fish (Konan et al., 2007; Tah et al., 2012; Koffi et al., 2014; Cicek et al., 2019). The b-value based on Froese, 2006 is between 2.5 and 3.5 or 2-4 (Tesch 1971), which all calculated $b$-values were within this expected ranges in this study.

Table1. Descriptive statistics and length-weight relationship parameters for three gobiid species from the Southern Caspian Sea basin 2012-2019

\begin{tabular}{|c|c|c|c|c|c|c|c|c|c|c|c|c|}
\hline \multirow{2}{*}{ Species } & \multirow{2}{*}{$\mathbf{n}$} & \multirow{2}{*}{$\begin{array}{l}\text { Total length } \\
(\mathrm{cm}) \\
\text { min-max }\end{array}$} & \multirow{2}{*}{$\begin{array}{l}\begin{array}{l}\text { Total } \\
\text { weight }(\mathrm{g})\end{array} \\
\text { min-max }\end{array}$} & \multicolumn{5}{|c|}{ LWR parameters } & \multirow{2}{*}{$\begin{array}{l}\text { Condition } \\
\text { factor }(K)\end{array}$} & \multirow{2}{*}{$\begin{array}{l}\text { Growth } \\
\text { pattern }\end{array}$} & \multirow[t]{2}{*}{$P$} & \multirow[t]{2}{*}{$t$} \\
\hline & & & & a & $b$ & $r^{2}$ & $95 \% \mathrm{CL}$ of $b$ & $95 \%$ CL of a & & & & \\
\hline P. bathybius & 165 & $6.95-28.36$ & $2.3-263.4$ & 0.003 & 3.32 & 0.988 & $3.28-3.35$ & $0.002-0.0047$ & $1.00 \pm 0.18$ & $\mathrm{~A}^{+}$ & $<0.05$ & 38.78 \\
\hline N. caspius & 102 & $8.20-13.20$ & $7.0-21.6$ & 0.032 & 2.47 & 0.831 & $2.25-2.70$ & $0.013-0.026$ & $0.98 \pm 0.12$ & $A^{-}$ & $<0.05$ & -75.81 \\
\hline N. pallasi & 178 & $4.92-12.55$ & $0.6-24.6$ & 0.003 & 3.45 & 0.902 & $3.25-3.67$ & $0.002-0.005$ & $0.94 \pm 0.18$ & $\mathrm{~A}^{+}$ & $<0.05$ & 59.48 \\
\hline
\end{tabular}

$\mathrm{N}=$ number of individuals; Min= minimum; Max= maximum; $a=$ intercept; $b=$ slope; $C L=$ confidence limits; $r^{2}=$ coefficient of determination.

In LWRs, $b$-values which are higher and lower than 3 indicated positive and negative allometric growth patterns, respectively. Based on the results, allometric growth pattern was positive for $P$. bathybius and N. pallasi, and negative for $N$. caspius. Abdoli et al. (2009) estimated the $b$-value of $P$. bathybius as 2.44 lower than our result (3.32). Aghajanpour et al. (2016) and Mahdipour et al. (2017) in their study reported $b$-value for $N$. caspius $2.85-3.0$ and 3.17 which is different with our study. LWR and $K$ parameters have been reported for the first time for $N$. pallasi from the Caspian Sea basin. LWRs may change during the events of life cycle, growth, and onset of maturity, gut fullness, sampling techniques, and availability of food (Le Cren, 1951).

\section{REFERENCES}

Abbasi, K., Mouludi-Saleh, A., Eagderi, S. \& Sarpanah, A. (2019). Lengthweight relationship and condition factor of eight species of the genera Capoeta, Garra, Chondrostoma, Schizothorax and Paraschistura from Iranian inland waters. Iranian Journal of Ichthyology, 6, 264-270.

Abdoli, A., Allahyari, S., Kiabi, B. H., Patimar, R., Ghelichi, A., Mostafavi, H., Aghili, S.M. \& Rasooli, P. 2009. Length-weight relationships for seven Gobiid fish species in the southeastern Caspian Sea basin, Iran. Journal of Applied Ichthyology, 25, 785-786 DOI: 10.1111/j.1439-0426.2009.01278.x

Aghajanpour, M., Haghparast, S., Raeisi, H. \& Jabale A.R. 2016. Growth parameters and mortality rate of Neogobius caspius (Eichwald, 1831) in southern part of the Caspian Sea (Teleostei: Gobiidae). Iranian Journal of Ichthyology, 3(2), 122-129.

Ali A.N., Dahanukarm R. \& Raghavan, B. (2013). Length-weight and lengthlength relationship of three species of snakehead fish, Channa
Fulton's condition factor $(K)$ of the studied species ranging 0.94 to 1.00 . Higher value of the condition factor indicates suitability of a specific water body for growth of fish (MouludiSaleh and Eagderi, 2019; Abbasi et al., 2019). The condition factor fluctuating is based on the seasonal variations of the gonads and feeding intensity (Biswas, 1993). Finding of the present study will be helpful in biological studies and fisheries management.

\section{ACKNOWLEDGEMENTS}

This study is a product of project No. 97014470, financially supported by the Iran National Science Foundation and University of Tehran. diplogramma, C. marulius and $C$. striata from the riverine reaches of Lake Vembanad, Kerala, India. Journal of Threatened Taxa, 5, 47694773. DOI: 10.11609/JoTT.03353.4769-73

Bagenal, T.B. (1978). Age and growth. In Methods for Assessment of Fish Production in Fresh Waters. 3rd ed., edited by Bagenal, T.B. Oxford: Blackwell Scientific Publications, pp 101-136.

Berg, L.S. (1949). Fishes of fresh waters of the USSR and adjacent countries. Moscow- Leningrad: Publishing house of Academy of Sciences of the USSR. Part 2: 456P.

Biswas, S.P. (1993). Manual of Methods in Fish Biology. South Asian Publishers, New Delhi.

Cherif, M.R., Zarrad, H., Gharbi, H. \& Jarboui, O. (2008). Length-weight relationships for 11 fish species from the Gulf of Tunis (SW Mediterranean Sea, Tunisia). Pan-American Journal of Aquatic Science, $3,1-5$. 
Cicek, E., Öztürk, S. \& Sungurm S. (2019). Some biological properties of Kura goby, Ponticola cyrius (Kessler 1874) (Gobiiformes, Gobiidae) from Kura River, Turkey. International Journal of Aquatic Biology, 7, 218-223. DOI: 10.22034/ijab.v7i4.706

Eagderi, S., Mouludi-Saleh, A. \& Cicek, E. (2020a). Length-weight relationship of ten species of Leuciscinae sub-family (Cyprinidae) from Iranian inland waters. International Aquatic Research, 12, 133-136. DOI: 10.22034/iar (20).2020.1891648.1004

Eagderi, S., Poorbagher, H., Çiçek, E. \& Sungur, S. (2020b). Length-weight relationships, condition factor and morphometric characteristics of ten Spirlin (Alburnoides Jeitteles 1861) species from Iranian inland waters. Survey in Fisheries Sciences, 7, 1-7.

Eagderi, S., Nikmehr, N. \& Poorbagher, H. (2020c). Ponticola patimari sp. nov. (Gobiiformes: Gobiidae) from the southern Caspian Sea basin, Iran. FishTaxa, 17, 22-31.

Esmaeili, H.R., Sayyadzadeh, G., Eagderi, S. \& Abbasi, K. (2018). Checklist of freshwater fishes of Iran. FishTaxa, 3, 1-95.

Froese, R. (2006). Cube law, condition factor and weight-length relationships: history, meta-analysis and recommendations. Journal of Applied Ichthyology, 22, 241-253. DOI: 10.1111/j.1439-0426.2006.00805.x

Froese, R. \& Pauly, D. (2008). Summary information on Gobiid fishes and Neogobius caspius. Retrieved from http://www.Fishbase.org, (07/2008).

Froese, R., Tsikliras, A.C. \& Stergiou, K.I. (2011). Editorial note on weightlength relations of fishes. Acta Ichthyologica et Piscatoria, 41, 261-263. DOI: 10.3750/AIP2011.41.4.01

Fulton. T.W. (1904). The rate of growth of fishes. 22nd Annual Report of the Fishery Board of Scotland, 3, 41-241.

Hammer, Ø., Harper, D.A.T. \& Ryanm, P.D. (2001). Past: paleontological statistics software package for education and data analysis. Palaeontologia Electron 4(4): 1-9.

Koffi, B.K., Berté, S. \& Koné, T. (2014). Length-weight relationships of 30 fish species in Aby Lagoon, Southeastern Côte d'Ivoire. Current Research Journal of Biological Sciences, 4, 173-178. DOI: 10.19026/crjbs.6.5517

Konan, A.K.F, Ouattara, M.A. \& Gourène, G. (2007). Weight-length relationship of 57 fish species of the coastal rivers in southeastern of Ivory Coast. Croatian Journal of Fisheries, 65, 49-60.
Le Cren, E.D. (1951). The length-weight relationship and seasonal cycle in gonad weight and condition in the perch Perca fluviatilis. The Journal of Animal Ecology, 20, 201-219. DOI: 10.2307/1540

Mahdipour, E, Alavi-Yeganeh M.S. \& Heidari A (2017) Length-weight and length-length relationships of two goby species, Neogobius caspius (Eichwald, 1831) and Proterorhinus nasalis (De Filippi, 1863) from the southern Caspian Sea" Journal of Applied Ichthyology, 33, 1277-1278.

Mouludi-Saleh A, Eagderi S. (2019). Length-weight relationship, and condition factor of ten fish species (Cyprinidae, Sisoridae, Mugilidae, Cichlidae, Gobiidae and Channidae) from Iranian inland waters. Journal of Wildlife and Biodiversity, 3, 12-15. DOI: 10.22120/jwb.2019.107947.1068

Mouludi-Saleh, A., Eagderi, S., Abbasi, K. \& Salavatian, S.M. (2021). Length-weight relationship and condition factor of ten fish species (Cypriniformes: Cyprinidae) from the Caspian Sea, Urmia Lake and Persian Gulf basins of Iran. Journal of Fisheries, 9(1), 91401. Retrieved from http://journal.bdfish.org/index.php/fisheries/article/view/JFish91401. (12/2/2021).

Muchlisin, Z.A., Musman, M. \& Azizah, M.N.S. (2010). Length-weight relationships and condition factors of two threatened fishes, Rasbora tawarensis and Poropuntius tawarensis, endemic to Lake Laut Tawar, Aceh Province, India. Journal of Applied Ichthyology, 26, 949-953. DOI: 10.1111/j.1439-0426.2010.01524.x

Rahimov, D.B. (1991). Goby fish of the Caspian Sea (systematic, ecology, value) Abstract. diss. Dr. biol. St. Petersburg: Sciences.85p.

Sarkar, U.K., Deepak, P.K. \& Negi, R.S. (2009). Length-weight relationship of clown knifefish Chitala chitala (Hamilton 1822) from the River Ganga basin, India. Journal of Applied Ichthyology, 25, 232-233. DOI: 10.1111/j.1439-0426.2008.01206.x

Tah, L., Gouli, G.B. \& Da Costa, K.S. (2012). Length-weight relationships for 36 freshwater fish species from two tropical reservoirs: Ayamé I and Buyo, Côte d'Ivoire. Revista de Biologia Tropical, 60, 1847-1856. DOI: 10.15517/rbt.v60i4.2185

Tesch, F.W. (1971). Age and growth. In W. E. Ricker (Ed.), Methods for assessment of fish, production in fresh waters. Blackwell Scientific Publications, Oxford. pp 98-130. DOI: 10.1002/iroh. 19690540313 